\title{
Motivation of Visiting Bako National Park
}

\author{
Thalany Kamri', Alias Radam² \\ 1 Universiti Teknologi MARA, Sarawak, Malaysia \\ 2 Universiti Putra Malaysia, Selangor, Malaysia \\ thalany@sarawak.uitm.edu.my
}

\begin{abstract}
This study was to analyse the visitors' motives of visiting Bako National Park. A total of 564 visitors were interviewed. Varimax rotation method in factor analysis was employed to gain information from visitors on their behaviour reflecting their motives for ecotourism activities in the national park. The results showed that visitors visit a national park for four factors: challenge excursion, social trip, nature tour and getaway outing. This result may help the management authority to reposition national park attributes without neglecting the objectives of the national park existence.
\end{abstract}

Keywords: national park; motivation; protection area; ecotourism

eISSN 2398-4279 @ 2018. The Authors. Published for AMER ABRA cE-Bs by e-International Publishing House, Ltd., UK. This is an open access article under the CC BY-NC-ND license (http://creativecommons.org/licenses/by$n c-n d / 4.0 /$ ). Peer-review under responsibility of AMER (Association of Malaysian Environment-Behaviour Researchers), ABRA (Association of Behavioural Researchers on Asians) and CE-Bs (Centre for EnvironmentBehaviour Studies), Faculty of Architecture, Planning \& Surveying, Universiti Teknologi MARA, Malaysia.

DOI: https://doi.org/10.21834/ajqol.v3i9.83 


\subsection{Introduction}

Motivation is basic strength behind human behaviour (Berkman and Gilson, 1978). This refers to the internal needs and wants that generate a state of disequilibrium within individuals (Crompton and McKay, 1997). Many studies have discussed the travel motivation in tourism literature. However, the discussion of motivation has not been expanded to the national park tourism in a developing country such as in Malaysia. This study adopted the motivation scale applied by Boxall and Adamowicz (2002). The aim of this paper is to understand why visitors visiting national parks by applying to the site Bako National Park (NP). These reasons of visiting would help the authorized management in promoting the national parks. Hence the result may be applied to other parks to improve the marketing strategies. National park supplies the most important part of tourism experience. This is because it is the only category of protected areas that can be visited and normally associated with ecotourism.

As ecotourism activities are motivated by nature, visitors' experiences occur almost entirely in the state's national parks. The state of Sarawak has plenty of nature and cultural based resources which yet to be fully explored. Visitors are attracted to visit a national park because of the natural surrounding and the environmental benefits that the site can offer. Ranging from easy strolls to hiking in parks on trails are among the most common recreation facilities provided in parks. Nature or built up trails provide an excellent way for visitors in exploring the natural areas hence, the most restorative of ecotourism activities (Oh and Hammitt, 2010). Visitors enter national parks with expectations. Accomodation facilities, park interpretation and information, wildlife observation and food and beverages are part of their concern. Hearne and Salinas (2002) demonstrated that both foreign and local visitors preferred improved infrastucture at the visitors' centre and more information about the area either written or oral presentation. In another research, these two populations had similar preference towards improved national park management and the presence of park guides for wildlife viewing (Hearne and Santos, 2005).

Visitors who decide to commit to ecotourism activities would want to experience it in the natural setting. Suh and Harrison (2005) stated that visitors experience of wilderness can be recognized as the highest valued service in the park. It was found that visitors preferences, level of satisfaction and importance onto the attributes in the park are affected by (a) previous experiences of visiting other parks, (b) prior knowledge about the park and (c) information that they learn and understand which can be a link to experience in the park (Arabatzis and Grigoroudis, 2010).

\subsection{Description of the Area}

Bako NP is located 37 kilometres to the east of the capital city of Kuching with the coordinates of $1^{\circ} 43^{\prime} \mathrm{N} 110^{\circ} 28^{\prime} \mathrm{E}$. The highest point has an altitude of $800 \mathrm{ft}$ from the sea level. Covering an area or 2,727 hectares or $27 \mathrm{~km}^{2}$, Bako NP is at the tip of the Muara Tebas peninsular. Lies on a rocky headland at the peninsular, the coastline is facing South China Sea. The area was named after mangrove's Rhizophora species. Local name for this species is bakau or bako as the native pronounce it. The name of a village was given as Bako Village or Kampong 
Bako. Kampong Bako, inhabit by the natives more than hundreds year ago, was established in 1853. Formerly known as Muara Tebas Forest Reserve in 1927, Bako NP was the first in Sarawak to be gazetted as a national park on 1 May 1957 and was opened to public on 4 May 1957.

Apart from its scientific value, Bako NP has a tremendous attraction for its animal and plant life together with the geological formation of the park. It has a wonderful mixture of forest, open heath land, cliffs, sandy beaches, formation of rock and packed with numerous wildlife species in such a limited park area (Lim, 1990). Chin et al. (2000) reported more than $90 \%$ of visitors responded that activities that were of importance when in Bako NP were to feel close to nature, observing and encountering wildlife.

\subsection{Methodology}

The target population for this study consist of local and foreign visitors to Bako NP. The sampling method used would be the traditional visitor monitoring surveys of the national park, which is a random sampling. The use of random sampling is to allow all visitors who come past the survey point have the equal chance to be asked for their willingness to take part in the survey.

There are 20 statements of possible reasons reflecting their attitude for visiting a national park as employed by Boxall and Adamowicz (2002). In the questionnaire, the researcher asked respondent to rate the statements based on 5 points Likert scale of how strongly they felt about a set of statements. This study employed Exploratory Factor Analysis (EFA) to identify the fundamental construct from a large set of control variables.

\subsection{Findings and Analysis}

\subsection{Visitors' Profile}

From a total of 564 respondents, $57.8 \%$ are foreign visitors and $42.2 \%$ are local visitors. The highest proportion of foreign respondents is from the European region (73.3\%). Of this percentage, $73.2 \%$ are from Netherland, United Kingdom, Germany and France. The highest local visitors are from Sarawak (54.2\%) followed by Kuala Lumpur $(23.5 \%)$. More than half of the respondents are male (53.4\%) compare to female (46.6\%). A majority $(71.3 \%)$ of the respondents are in the 20 to 39 years of age group. Only $4.8 \%$ are below 20 years old and $10.1 \%$ are over 50 years old. The respondents that are over 50 years of age are mostly foreigners (14.7\%) compare to only $3.8 \%$ locals (refer to Table 1). This coincides with the statistics on work status where $4.6 \%$ retirees are foreigners and only $1.7 \%$ is locals. 
Table 1. Visitor's profiles

\begin{tabular}{lll}
\hline Characteristics & $\%$ & $\mathbf{n}$ \\
\hline Gender & & \\
Male & 53.4 & 301 \\
Female & 46.6 & 263 \\
Origin & & \\
Foreign & 57.8 & 326 \\
Local & 42.2 & 238 \\
Age & & \\
<20 & 4.8 & 27 \\
$20-29$ & 45.1 & 254 \\
$30-39$ & 26.2 & 148 \\
$40-49$ & 13.8 & 78 \\
$50-59$ & 6.4 & 36 \\
$\geq 50$ & 3.7 & 21 \\
Education level & & \\
Postgraduate degree & 37.8 & 213 \\
Undergraduate degree & 43.6 & 246 \\
Secondary school & 17.8 & 100 \\
Primary school & 0.8 & 5 \\
Occupation & & \\
Employed & 75.5 & 426 \\
Seeking employment & 8.9 & 50 \\
Retired & 3.4 & 19 \\
Others & 12.2 & 69 \\
Monthly Income & & \\
< RM3000 & 33.1 & 187 \\
RM3000 - RM6000 & 21.3 & 120 \\
RM6001 - RM9000 & 15.6 & 88 \\
$>$ RM9000 & 30.0 & 169 \\
\hline
\end{tabular}

\subsection{Characteristics of visits}

More than half of both foreign (83.5\%) and local (54.6\%) visitors have been to at least one national park before. From this total, only $7.4 \%$ of foreign and $18.5 \%$ of locals has visited Bako NP before. The results also show that $64.1 \%$ of foreign and $79.8 \%$ of local respondent will visit Bako NP again in the future.

More than half of visitors in this study (64.4\%) prefer to seek guidance of park guides. The remaining (35.6\%) need privacy and able to explore the park by themselves. $95.2 \%$ of the visitors were expressing that it was worth to pay the entrance fee to the activities that they had experienced. Finally, more than half of visitors in this study $(76.7 \%)$ prefer to visit as a day trip only. While $23.3 \%$ of them prefer to stay on the average of 2 nights. 
Table 2: Characteristics of visits

\begin{tabular}{llll}
\hline Statement & Response & Foreign (\%) & Local (\%) \\
\hline Respondent has been to at least one national & Yes & 83.5 & 54.6 \\
park before & No & 16.5 & 45.4 \\
Respondent has visited Bako NP before & Yes & 7.4 & 18.5 \\
& No & 92.6 & 81.5 \\
Respondent will visit Bako NP again in the & Yes & 64.1 & 79.8 \\
future & No & 27.3 & 18.5 \\
& Maybe & 8.6 & 1.7 \\
\hline
\end{tabular}

\subsection{Visitors' motives in visiting Bako NP}

The overall result in Table 3 shows that respondents are positively agree with all the statements except for the statement $\boldsymbol{c}$ : To do things with other people. More than half responded disagree $(27.1 \%)$ and neutral $(44.9 \%)$ with this reason of park visit. Statements $\boldsymbol{h}, \boldsymbol{i}, \boldsymbol{j}, \boldsymbol{I}$ and $\boldsymbol{s}$ shows that more than $70 \%$ of the respondents highly agree and strongly agree to the reason of visits which are $83.3 \%, 86.6 \%, 78.7 \%, 81.2 \%$ and $72 \%$ respectively. The highest response for strongly agree was to develop skills $(52.7 \%)$ as the reasons of the national park visits. This followed by $41.5 \%$ strongly agreed to the reason of feeling independent.

\section{Statement}

a. To strengthen relationships with friends or family

b. To be with my friends or family

c. To do things with other people

d. To be with people of similar interests

e. To get away from everyday routine

f. To relieve my tensions

g. To escape from the pressures of work

h. To challenge my skills and abilities

i. To develop my skills

j. To challenge nature

k. To feel free from society's restrictions

I. To feel independent

$m$. To observe the beauty of nature

$n$. To enjoy the sights, sounds and smells

of nature

o. To feel close to nature

p. To find quiet places

q. To be in charge of a situation

$r$. To obtain a feeling of harmony with nature

s. To be alone

t. To be away from other people
Table 3: Percentage of visit motives

$\begin{array}{lllll}\begin{array}{l}\text { Strongly } \\ \text { disagree } \\ (\%)\end{array} & \begin{array}{l}\text { Disagree } \\ (\%)\end{array} & \begin{array}{l}\text { Neutral } \\ (\%)\end{array} & \begin{array}{l}\text { Agree } \\ (\%)\end{array} & \begin{array}{l}\text { Strongly } \\ \text { Agree (\%) }\end{array} \\ 4.6 & 16.1 & 35.8 & 38.8 & 4.6 \\ 2.5 & 19.1 & 39.2 & 36.3 & 2.8 \\ 5.1 & 27.1 & 44.9 & 20.7 & 2.1 \\ 2.5 & 14.9 & 36.5 & 38.8 & 7.3 \\ 2.3 & 12.4 & 35.3 & 38.1 & 11.9 \\ 4.1 & 11.5 & 30.7 & 44.3 & 9.4 \\ 8.2 & 22.9 & 36.2 & 26.4 & 6.4 \\ 0.0 & 2.0 & 14.7 & 45.2 & 38.1 \\ 0.0 & 0.9 & 12.6 & 33.9 & 52.7 \\ 0.2 & 1.8 & 19.3 & 44.5 & 34.2 \\ 0.7 & 4.6 & 27.3 & 46.8 & 20.6 \\ 0.0 & 1.1 & 17.7 & 39.7 & 41.5 \\ 2.7 & 12.4 & 37.6 & 36.9 & 10.5 \\ 3.9 & 17.0 & 38.8 & 32.4 & 7.8 \\ 3.4 & 13.3 & 39.9 & 36.7 & 6.7 \\ 2.7 & 12.9 & 40.8 & 37.4 & 6.2 \\ 1.4 & 8.2 & 27.5 & 45.6 & 17.4 \\ 1.2 & 8.5 & 32.3 & 43.1 & 14.9 \\ 0.7 & 5.5 & 21.8 & 49.5 & 22.5 \\ 5.7 & 19.7 & 38.8 & 27.1 & 8.7\end{array}$

Out of these 20 items, 18 have loadings greater than 0.5 and were retained for further analysis. Only factors with Eigen value larger than 1.0 will be extracted. The internal 
consistency or reliability of the items was evaluated using Cronbach's alpha. As a result of that, four factors were extracted with the eigenvalues of above 1.0 and the total variance of 59.274 percent. These four factors were given names based on their common themes identified across the statements in survey questions. These four factors were labelled as a nature tour, challenge excursion, social trip and getaway outing as shown in Table 4.

Table 4: Visit motives of previous research

\begin{tabular}{l}
\hline Challenge and freedom \\
to challenge my skills and abilities \\
to develop my skills \\
to be in charge of a situation \\
to feel independent \\
to feel free from society's restrictions \\
to challenge nature \\
to be alone \\
Nature appreciation \\
to feel close to nature \\
to observe the beauty of nature \\
to obtain a feeling of harmony with nature \\
to find quiet places \\
to enjoy the sights, sounds, and smells of nature \\
Social relationships \\
to be with my friends or family \\
to strengthen relationships with friends or family \\
to do things with other people \\
to be with people with similar interests \\
Escape from routine \\
to escape from the pressures of work \\
to relieve my tensions \\
to get away from my everyday routine \\
to be away from other people
\end{tabular}

The KMO measure of sampling adequacy is 0.797 which is larger than 0.6 . On the other hand, a significant Bartlett's Test of sphericity results with Chi-Square $=4956.955$ further support the factorability of the correlation matrix.

Table 5 shows that respondents visiting Bako NP for challenge excursion. This challenge excursion factor has a reliability coefficient of alpha $=0.84$. This factor can explain $24.706 \%$ of the variance in the five items loaded.

Table 5: Factor loadings on visiting motivation factors of "challenge excursion"

\begin{tabular}{lcc}
\hline Items & $\begin{array}{c}\text { Factor } \\
\text { loading }\end{array}$ & $\begin{array}{c}\text { Cronbach's } \\
\text { alpha }\end{array}$ \\
\hline Challenge Excursion & & 0.840 \\
To develop my skills & 0.864 & \\
To challenge my skills and abilities & 0.823 & \\
To feel independent & 0.796 & \\
To challenge nature & 0.728 & \\
To feel free from society's restrictions & 0.598 & \\
\hline
\end{tabular}


Table 6 shows that respondents visiting Bako NP for social trip. This social trip factor has a reliability coefficient of alpha $=0.816$. This factor can explain $15.873 \%$ of the variance in the six items loaded.

Table 6: Factor loadings on visiting motivation factors of "social trip"

\begin{tabular}{lcc}
\hline Items & $\begin{array}{c}\text { Factor } \\
\text { loading }\end{array}$ & $\begin{array}{c}\text { Cronbach's } \\
\text { alpha }\end{array}$ \\
\hline Social trip & 0.816 & 0.816 \\
To strengthen relationships with friends or family & 0.812 & \\
To be with my friends or family & 0.771 & \\
To do things with other people & 0.644 & \\
To be with people of similar interests & 0.584 & \\
To relieve my tensions & 0.547 & \\
To get away from everyday routine & 3.175 & \\
\hline Eigen values & 15.873 & \\
$\%$ of variation & & \\
\hline
\end{tabular}

Table 7 shows that respondents visiting Bako NP for nature tour. This social trip factor has a reliability coefficient of alpha $=0.794$. This factor can explain $10.226 \%$ of the variance in the four items loaded.

Table 7: Factor loadings on visiting motivation factors of "nature tour"

\begin{tabular}{lcc}
\hline Items & Factor loading & Cronbach's alpha \\
& & 0.794 \\
\hline Nature tour & 0.854 & \\
To observe the beauty of nature & 0.851 & \\
To enjoy the sights, sounds and smells of nature & 0.745 & \\
To feel close to nature & 0.580 & \\
To find quiet places & 2.045 & \\
\hline Eigen values & 10.226 & \\
$\%$ of variation & & \\
\hline
\end{tabular}

Table 8 shows that respondents visiting Bako NP for nature tour. This social trip factor has a reliability coefficient of alpha $=0.859$. This factor can explain $8.469 \%$ of the variance in the three items loaded. 
Table 8: Factor loadings on visiting motivation factors of "nature tour"

\begin{tabular}{lcc}
\hline Items & Factor loading & Cronbach's alpha \\
\hline Getaway outing & & 0.859 \\
To obtain a feeling of harmony with nature & 0.838 & \\
To be alone & 0.831 & \\
To be in charge of a situation & 0.820 & \\
\hline Eigen values & 1.694 & \\
\% of variation & 8.469 & \\
\hline
\end{tabular}

All the items in these four factors were found to have high factor loading of more than 0.5 . The factor loading are ranging from 0.547 to 0.864 and communalities ranging from 0.376 to 0.787 . The coefficient of more than 0.5 for the factor loading by Hair et al. (2010) is used as a benchmark to indicate a realistic loading for each item.

\subsection{Discussions and Conclusion}

Reliability is a major concern in research which involves scale in determining motivation of visitors' visit. Reliability refers to the repeatability of the result by using the same measurement. This study developed a scale of motivations to visit Bako NP by following the items recommended by Boxall and Adamowicz (2002).

There are several marketing implications can be drawn from this study. First, "Challenge excursion" was found to be the strongest motivation in the survey. This suggests that visitors associate visiting a national park for ecotourism activities such as developing skills, abilities and to challenge the nature. These are their primary reasons which motivate them to visit a national park. Therefore, the promotion of this park should demonstrate visitors enjoying their independent with nature and from society's restrictions in order to develop their skills and abilities. Secondly, different motivations to visit were identified in this study. This suggests that although visitors are motivated by the feeling of independent, they may also expect to visit with others who have similar interest which could be friends or family. The park may offer discounts to those who bring a new family member or friend. This may not only encourage bonding time with friends on the cruise, but also attract new visitors and expand the ecotourism market. To respond to "Nature tour" and "Getaway outing", different strategies may also be implemented. This suggests that visitors need to find quiet places to feel close to nature and to be alone. They are motivated by relaxing and escaping aspects of ecotourism. From the data analysis, it can be concluded that the quality of services, visitor's identification (Rahadi, 2012) as well marketing strategies play a significant part for visitors revisit behaviour in the national park.

Given that the increasing popularity of ecotourism in the national park in Asia countries and scarcity of research in this topic, this result is believed an additional contribution to the literature. It is also hoped that this may become a stepping stone to further investigation in this topic. 


\section{Acknowledgement}

The author would like to thank the SFC and Sarawak Forest Department in providing necessary information for the purpose of this study. In addition, the author is grateful to Mimi Liana Abu for many meaningful discussions on this topic.

\section{References}

Arabatzis, G., \& Grigoroudis, E. (2010). Visitors' satifaction, perception and gap analysis: The case of DadiaLefkimi-Souflion National Park. Forest Policy and Economics, 12, 163-172.

Backhaus, N. (2003). 'Non-place jungle': The construction of auhenticity in national parks of Malaysia. Indonesia and the Malay World , 31 (89), 151-160.

Berkman, H. W., \& Gilson, C. C. (1978). Consumer behavior: Concepts and strategies. Belmont, California: Dickenson Press.

Boxall, P. C., \& Adamowicz, W. L. (2002). Understanding heterogenous preferences in random utility models: A latent class approach. Environmental and Resource Economics , 23 (4), 421-446.

Chin, L. M., Moore, S. A., Wallington, T. J., \& Dowling, R. K. (2000). Ecotourism in Bako National Park, Borneo: Visitors' perspectives on environmental impacts and their management. Journal of Sustainable Tourism , 8 (1), 20 35 .

Chui, T. B., Faizah, A. R., Faridah, H., Rosidah, M., Jamaliah, M. Y., \& Rohiyati, H. (2010). Exploring tourist experiencescape and servicescape at Taman Negara (National Park Malaysia). International Journal of Trade, Eonomics and Finance , 1 (1), 28-31.

Crompton, J. L., \& McKay, S. L. (1997). Motives of visitors attending festival events. Annals of Tourism Research, 24 (2), 425-439.

Dixit, S. K., \& Narula, V. K. (2010). Ecotourism in Madhav National Park: Visitors' perspectives on environmental impacts. South Asian Journal of Tourism and Heritage , 3 (2), 109-115.

Hair, J. F., Black, W. C., Babin, B. J., \& Anderson, R. E. (2010). Multivariate Data Analysis: A Global Perspective. London: Pearson.

Hearne, R. R., \& Salinas, Z. M. (2002). The use of choice experiments in the analysis of tourist preferences for ecotourism development in Costa Rica. Environmental Management , 65 (2), 153-163.

Hearne, R. R., \& Santos, C. A. (2005). Tourists' and locals' preferences toward ecotourism development in the Maya Biosphere Reserve, Guatemala. Environment, Development and Sustainability , 7 (3), 303-318.

Lim, M. T. (1990). Photofeature: Bako National Park. Malayan Naturalist , 43 (4), 19. MOCAT \& WWF. (1995). National Ecotourism Plan: Malaysia (Vols. Part 1-6). Petaling Jaya: Ministry of Culture, Arts and Tourism and World Wildlife Fund.

Oh, C., \& Hammitt, W. E. (2010). Determining economic benefits of park trails: Management implications. Journal of Park and Recreation Administration , 28 (2), 94-107.

Suh, J., \& Harrison, S. (2005). Management objectives and economic value of national parks: Preservation, conservation and development. Discussion Paper. Queensland, Australia: The University of Queensland. 